\title{
Conservação da água aplicada a uma indústria de papelão ondulado
}

\author{
Water conservation applied to a corrugated packaging plant
}

\author{
Cristiano Corrêa Weber \\ Engenheiro Civil pela Universidade Federal do Rio Grande do Sul (UFRGS). Mestrando em Recursos Hídricos e Saneamento Ambiental do Instituto de \\ Pesquisas Hidráulicas da UFRGS. Supervisor de Meio Ambiente da Trombini Industrial S/A

\section{Luiz Fernando Cybis} \\ Engenheiro Civil pela UFRGS. Doutor em Engenharia Sanitária e Ambiental pela University of Leeds. Professor Adjunto do Instituto de Pesquisas Hidráulicas \\ da UFRGS

\section{Lademir Luiz Beal} \\ Engenheiro Químico pela Universidade Federal do Rio Grande (FURG). Doutor em Recursos Hídricos e Saneamento Ambiental pelo Instituto de Pesquisas \\ Hidráulicas da UFRGS. Professor Adjunto do Centro de Ciências Exatas e Tecnologia da Universidade de Caxias do Sul (UCS)
}

\section{Resumo}

O principal objetivo deste artigo foi estabelecer estratégias para a conservação da água em uma indústria de embalagens de papelão ondulado (PO). O uso racional e o reúso da água foram as ferramentas de conservação escolhidas para melhorar o desempenho ambiental da planta estudada. Após essas intervenções, o consumo médio de água foi reduzido em 45\%, e o consumo específico caiu de 213,11 para 89,41 mL de água por metro quadrado de PO. Como resultado final, além da redução no consumo de água, os efluentes tratados passaram a cumprir a legislação ambiental.

Palavras chave: conservação da água; uso racional; reúso da água; indústria; papelão ondulado.

\section{Abstract}

The main goal of this article was to establish water conservation strategies in a corrugated packaging plant. The rational use and reuse of water were conservation tools chosen to improve the environmental performance of this plant. After these conservative interventions, the plant average water consumption was reduced at $45 \%$, and the specific consumption decreased from 213.11 to $89.41 \mathrm{~mL}$ of water per square meters of PO. As final result, besides water consumption reduction, the wastewater streams began to comply with the environmental legislation.

Keywords: water conservation; rational use; water reuse; industry; corrugated paperboard.

\section{Introdução}

O aumento da população mundial, somado ao consumo crescente dos recursos hídricos, colabora para uma perspectiva futura de escassez da água. A redução dos volumes disponíveis para cada habitante e a degradação de sua qualidade são os dois aspectos que configuram esse quadro de escassez: quantidade e qualidade (FIESP, 2004).

Inserido nesse contexto encontra-se o segmento industrial, que é responsável por, aproximadamente, 25\% do consumo mundial de água e é constituído por atividades potencialmente poluidoras (MANCUSO; SANTOS, 2003). A indústria de embalagens de papelão ondulado (PO), por exemplo, ao utilizar tintas recalcitrantes aos processos de tratamento convencionais, representa importante capacidade poluidora. Os corantes azoicos, constituintes dessas tintas, chegam aos corpos receptores após passarem pelo tratamento de efluentes e, quando incorporados às águas de abastecimento, oferecem risco de câncer aos seres humanos (DEPA, 1998). Além desses riscos, os corantes azoicos elevam as cargas de $\mathrm{DBO}_{5}$, DQO e de nitrogênio total Kjeldhal (NTK) dos efluentes lançados, colaborando para a degradação da qualidade dos corpos receptores.

A escassez da água, seja ela causada por consumo excessivo ou por poluição, encontra solução por meio das ferramentas de conservação. Segundo o New Mexico Office of the State Engineer (1999), a conservação é definida como toda e qualquer ação que reduza a quantidade de 
água extraída da natureza, seu consumo, suas perdas e desperdícios, e que torne seu uso mais eficiente, promovendo sua reciclagem e seu reúso ou prevenindo sua poluição. Contudo, Wan Alwi et al. (2008) acrescentam que a maximização dos resultados dessas ações deve ser obtida por meio do ordenamento destas, conforme a priorização apresentada a Figura 1 .

Neste trabalho, estudou-se uma indústria de embalagens de PO da região Nordeste do Rio Grande do Sul, cujo sistema de tratamento de efluentes encontrava dificuldades em atender os padrões de lançamento estabelecidos pelo órgão ambiental e seu consumo da água era excessivo nas atividades produtivas desenvolvidas. A solução desse problema e o incremento do desempenho ambiental da planta fabril foram buscados por meio da aplicação das técnicas de conservação da água, conforme apresentado na Figura 1.

\section{Metodologia}

A primeira etapa do estudo consistiu na elaboração de um diagnóstico inicial de uso da água na indústria. Para tanto, indicadores foram estabelecidos de modo que representassem o atendimento à legislação ambiental - premissa básica de um sistema de gerenciamento ambiental (Sans et al., 1998) - e a conservação da água em quantidade e em qualidade.

Os indicadores fornecidos pela legislação ambiental advieram da Licença de Operação (LO) da fábrica, emitida pela Fundação Estadual de Proteção Ambiental Henrique Luiz Roessler (FEPAM) e da outorga do poço tubular, fonte de abastecimento de água da empresa, emitida pela Secretaria Estadual do Meio Ambiente do Rio Grande do Sul (SEMA). O não-atendimento dos limites de emissão de efluentes para $\mathrm{DBO}_{5}, \mathrm{DQO}, \mathrm{NTK}_{\text {e }} \mathrm{P}_{\text {total }}$ (fósforo total), presentes na LO, e dos limites de consumo diário e de nível de água presentes na outorga do poço gerava não-conformidades legais. O percentual dessas nãoconformidades sobre o total de registros compôs os indicadores de atendimento à legislação.

Referentemente à conservação da água, três indicadores foram estabelecidos: o consumo específico de água (CEA), o nível do poço tubular (NAP) e as cargas dos poluentes $\mathrm{DBO}_{5}\left(\right.$ Carga $\left._{\mathrm{DBO}}\right)$, DQO $\left(\right.$ Carga $\left._{\mathrm{DQO}}\right)$, NTK (medido como N, Carga $\left.{ }_{\mathrm{NTK}}\right)$ e $\mathrm{P}_{\text {total }}\left(\right.$ Carga $\left._{\mathrm{P}}\right)$ lançadas ao corpo receptor, representando CEA e NAP a preservação da água em quantidade e os demais indicadores em qualidade. O CEA foi calculado de acordo com volume de água consumido $(\mathrm{mL})$ para produzir $1 \mathrm{~m}^{2}$ de $\mathrm{PO}$ ( $\mathrm{m}^{2} \mathrm{PO}$ ); logo, é expresso na unidade $\mathrm{mL} / \mathrm{m}^{2}$ PO. O NAP representa a profundidade da lâmina d'água do poço tubular medida a partir de sua superfície. Os indicadores de qualidade (cargas de poluentes), por sua vez, foram compostos por meio da multiplicação da concentração de cada poluente presente no efluente tratado, pela vazão média lançada ao corpo receptor.

De posse dos indicadores, iniciou-se a identificação dos pontos de consumo de água e de geração de efluentes. Esse passo é fundamental para a determinação dos tipos de uso da água praticados e das oportunidades de racionalização do uso e do reúso. Para tanto, foram realizadas visitas de campo, análise de documentos históricos e instalação de medidores de vazão nos setores consumidores de água, conforme proposto por Sautchúk (2004). Os dados resultantes desses levantamentos foram organizados em gráficos de barras dispostas em ordem decrescente de consumo de água, conforme os setores e os tipos de uso identificados.

Os setores e usos de maior consumo receberam a atenção inicial na busca de oportunidades de conservação da água. As primeiras ações adotadas seguiram a priorização exposta na Figura 1, ou seja, a racionalização do uso da água. Para tanto, as perdas físicas e os hábitos e procedimentos operacionais que geravam desperdício foram identificados e, consecutivamente, intervenções de ordem comportamental e física foram adotadas. As intervenções comportamentais foram compostas por medidas de caráter educativo, visando obter mudanças de hábito no uso da água por meio da conscientização (CORRAL-VERDUGO, 2002). As intervenções físicas, por sua vez, passaram pela eliminação de perdas de água, tais como vazamentos em tubulações e reservatórios, e de desperdícios por processos ineficientes de uso.

Esgotadas as oportunidades de racionalização do uso, partiu-se para a identificação das oportunidades de reúso da água. Estudou- 
se o reúso de efluentes brutos e de efluentes tratados em substituição à água de poço tubular nos processos produtivos, ou seja, o reúso não-potável da água. Os processos capazes de receber água de reúso foram elencados e tiveram sua qualidade e quantidade mínima de água determinadas. Depois de verificadas essas demandas, verificaram-se as fontes de oferta de água de reúso disponíveis. Parâmetros de qualidade e de quantidade da água proveniente dessas fontes também foram determinados. Após esses levantamentos, analisaram-se as possibilidades de reúso caso a caso, realizando-se as alocações de água viáveis conforme o tipo de uso. A ordem de estudo e implantação das atividades de reúso seguiu a premissa de não se usar água com qualidade superior à mínima necessária a cada tipo de uso.

Ao final do estudo, após as intervenções de racionalização do uso e do reúso da água terem sido aplicadas à planta fabril, realizou-se uma análise dos resultados dessas ações. Avaliou-se novamente, sob os critérios de desempenho estabelecidos na etapa de diagnóstico, o atendimento à legislação ambiental e a conservação da água em quantidade e em qualidade. Os resultados encontrados foram confrontados com os valores iniciais, determinando-se o incremento obtido no desempenho ambiental do empreendimento.

\section{Resultados e discussão}

\section{Diagnóstico da empresa}

Os parâmetros de emissão de efluentes ao corpo receptor $-\mathrm{DBO}_{5}$, $\mathrm{DQO}, \mathrm{NTK}$ e $\mathrm{P}_{\text {total }}$ - encontravam-se em desacordo com os limites estabelecidos na LO emitida pela FEPAM. A Tabela 1 mostra que as concentrações de nutrientes no efluente tratado, representadas por NTK e $\mathrm{P}_{\text {total }}$, excediam, respectivamente, os limites máximos de lançamento em 82 e $65 \%$ dos laudos de análise observados. Com relação à matéria orgânica carbonácea passível de degradação, representada pela $\mathrm{DBO}_{5}$ e $\mathrm{DQO}$, as não-conformidades eram menos frequentes; contudo, ainda havia o desrespeito à legislação. Similarmente ao que ocorria com os parâmetros de qualidade do efluente tratado, o limite máximo de consumo de água do poço tubular, estabelecido em outorga emitida pela SEMA, era ultrapassado em algumas situações, chegando a alcançar uma média de 149m²/dia em maio de 2006, ou seja, $29 \mathrm{~m}^{3} /$ dia acima do máximo determinado. Isso significa que, à exceção do NAP, todos os parâmetros de controle estabelecidos legalmente encontravam-se não-conformes entre 27 e $82 \%$ das vezes.

Quanto aos indicadores de conservação da água adotados, obteve-se CEA e NAP de $213,11 \mathrm{~mL} / \mathrm{m}^{2} \mathrm{PO}$ e $54,10 \mathrm{~m}$, respectivamente. As cargas lançadas ao corpo receptor, considerando-se uma vazão média de efluente tratado de $37 \mathrm{~m}^{3} /$ dia, chegaram aos valores de 6,03, 13,60, 1,30 e 0,09kg/dia, respectivamente para Carga ${ }_{\mathrm{DBO} 0}$, Carga $_{\mathrm{DQO}}$, Carga $_{\mathrm{NTK}}$ e Carga $\mathrm{P}_{\mathrm{P}}$

Tais indicadores, representando o atendimento à legislação ambiental e a situação inicial de conservação da água, apontavam para a necessidade imediata de se melhorar o desempenho do uso da água e da geração de efluentes da planta estudada. A identificação dessas oportunidades de melhoria passou, inicialmente, pela identificação dos usos da água. O seu consumo foi, então, classificado como produtivo e não-produtivo conforme a finalidade do uso. O primeiro tipo envolve as atividades que consomem água na área fabril e de utilidades, e o segundo tipo envolve as atividades chamadas de atividades de apoio.

O uso da água no setor produtivo da planta industrial ocorre nas áreas de ondulação, de impressão e de tratamento de efluentes. No setor de ondulação, a água é consumida nos seguintes pontos: produção de vapor, fabricação de adesivo de amido, produção de água refrigerada, diluição da resina de impermeabilização do papel, sistemas de limpeza de máquina e aplicação direta sobre o papel, como pode ser visto na Figura 2.

A área de impressão consome água principalmente quando as impressoras trocam a embalagem que está em produção por outra que requer cores distintas daquelas que estão sendo usadas. Exerce-se, então, a limpeza de todo o sistema de impressão, gerando o consumo de água e a emissão de efluentes. Além dessa, ocorrem limpezas periódicas de manutenção, nas quais as partes móveis das impressoras são desmontadas e lavadas em uma cabine. Existe, também, uma área que coordena a logística de fornecimento de tintas e de peças de impressão (clichês) às impressoras, chamada de sala de tintas. Nela, consome-se água durante a lavagem das embalagens vazias de tinta e dos clichês.

Tabela 1 - Dados estatísticos sobre a qualidade do efluente tratado, consumo de água e nível do poço tubular

\begin{tabular}{|c|c|c|c|c|c|c|}
\hline \multirow[b]{2}{*}{ Período de junho/2003 a janeiro/2007 } & \multicolumn{4}{|c|}{ Efluente final tratado } & \multicolumn{2}{|c|}{ Poço tubular } \\
\hline & $\begin{array}{l}\mathrm{DBO}_{5} \\
(\mathrm{mg} / \mathrm{L})\end{array}$ & $\begin{array}{c}\text { DQO } \\
(\mathrm{mg} / \mathrm{L})\end{array}$ & $\begin{array}{c}\text { NTK } \\
(\mathrm{mg} / \mathrm{L})\end{array}$ & $\begin{array}{c}P_{\text {total }} \\
(\mathrm{mg} / \mathrm{L})\end{array}$ & $\begin{array}{l}\text { NAP } \\
(\mathrm{m})\end{array}$ & $\begin{array}{l}\text { Vazão } \\
\text { (m³/dia) }\end{array}$ \\
\hline Média & 163,06 & 367,53 & 35,10 & 2,31 & 54,10 & 101,86 \\
\hline Desvio padrão & 123,67 & 238,50 & 29,51 & 2,12 & 0,93 & 32,29 \\
\hline Limite mínimo legal & & & & & 51,68 & \\
\hline Limite máximo legal & 135 & 405 & 10 & 1 & 57,43 & 120 \\
\hline Observações (un) & 72 & 72 & 72 & 72 & 658 & 129 \\
\hline Não-conformidades (un) & 37 & 26 & 59 & 47 & 0 & 35 \\
\hline Não-conformidades (\%) & 51 & 36 & 82 & 65 & 0 & 27 \\
\hline
\end{tabular}

NAP: nível do poço tubular; un: unidade. 


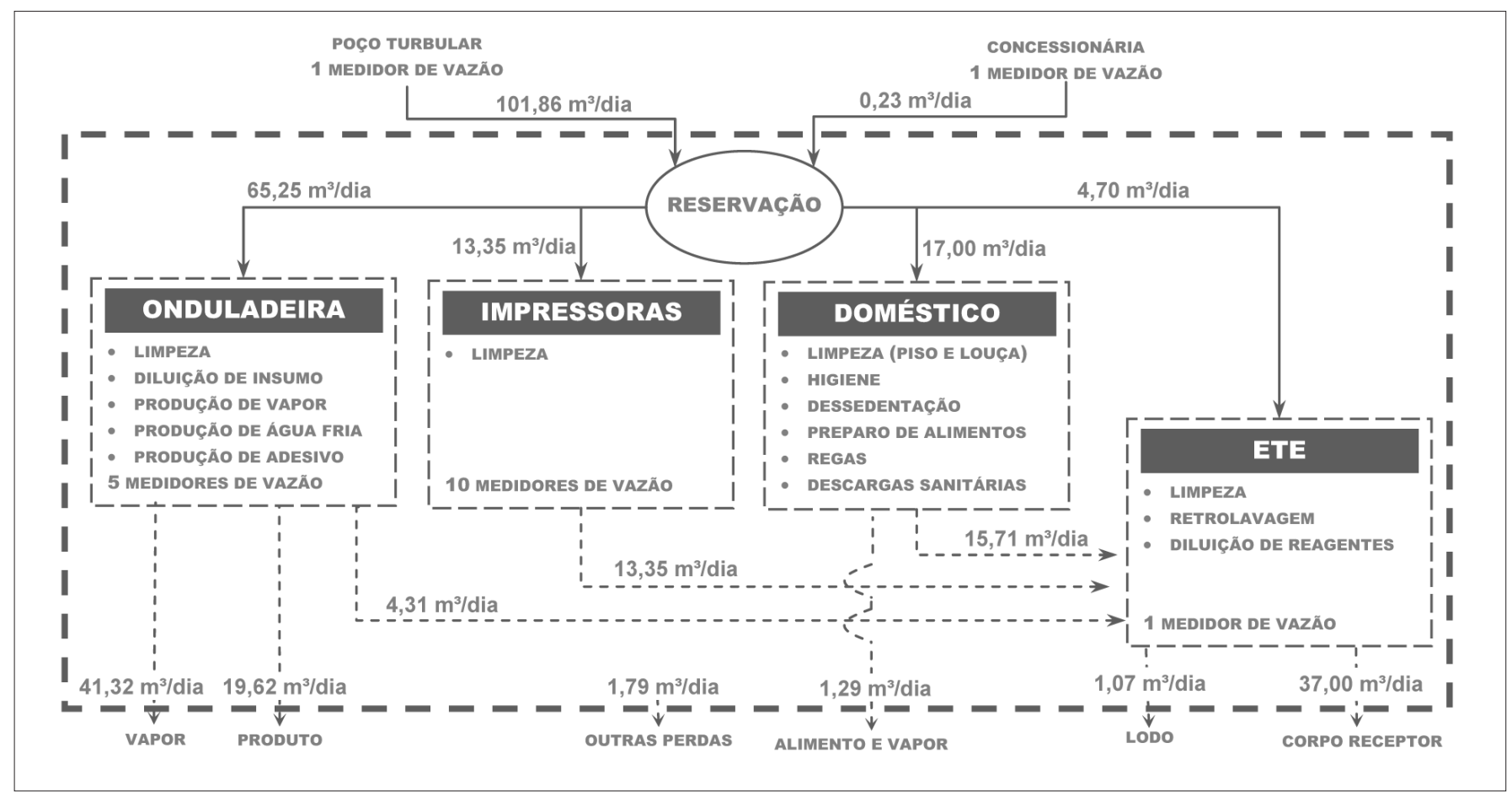

Figura 2 - Diagrama de fluxos para o consumo de água e para a geração de efluentes na fábrica estudada (linhas cheias representam os fluxos de água entrando no sistema e nos processos; e as linhas tracejadas, as perdas de volumes dos processos e do sistema através de efluentes, vapores e água incorporada ao produto). ETE: estação de tratamento de efluentes.

$\mathrm{Na}$ estação de tratamento de efluentes (ETE), o consumo da água ocorre durante a diluição de reagentes, nas operações de retrolavagem dos filtros e nos processos de limpeza.

Os usos não-produtivos da água são: descargas sanitárias, higiene pessoal, limpeza de louças e preparo de refeições, dessedentação humana e rega de jardins.

Conhecidos os tipos e pontos de uso da água, instalaram-se medidores de vazão, com a finalidade de se obterem registros de consumo por setor e por tipo de uso, priorizando-se os setores de produção. Um total de 15 medidores de vazão foi instalado na onduladeira e nas impressoras (Figura 2) e, nos setores que não receberam medidores, o consumo de água foi estimado.

Ordenando-se os dados de vazão adquiridos, por setor e por tipo de uso, obtiveram-se os gráficos da Figura 3. Ao analisá-los, observase que o consumo majoritário da água ocorria no setor de ondulação, representando $64 \%$ do consumo total de água da planta. O setor de impressão era o segundo maior consumidor para fins produtivos, com 13\% do consumo de água da fábrica que, somado ao setor de ondulação, acumulava $77 \%$ do consumo diário médio de água da empresa $\left(78,60 \mathrm{~m}^{3} / \mathrm{dia}\right)$.

De acordo com o tipo de uso, a Figura 3 mostra que $76 \%$ do uso da água ocorriam em três atividades: produção de vapor e de água fria (ondulação); produção de adesivo de amido (ondulação) e limpeza de máquinas, equipamentos e peças de impressão (ondulação, impressão e ETE).

\section{Uso racional da água}

Após a instalação de hidrômetros e obtenção dos primeiros registros de consumo de água, iniciou-se um trabalho focado na mudança comportamental quanto ao uso desse recurso natural. A inclusão dos setores consumidores em um programa de treinamento e de conscientização sobre a importância da preservação da água foi o cerne das intervenções comportamentais.

Visto que os processos de limpeza dos equipamentos eram em sua maioria manuais, as ações foram focadas nos operadores de onduladeira e de impressoras. A primeira etapa ocorreu em sala, com uma explicação sobre a importância da água para o homem e para o meio ambiente, seguida de acompanhamento nas áreas de trabalho. A segunda etapa ocorreu por meio da participação na limpeza do arroio Centenário, corpo receptor dos efluentes domésticos e industriais tratados, proporcionando aos envolvidos a visão real sobre a gravidade do problema abordado.

Devido à existência na onduladeira de uma metodologia de limpeza padrão que contemplava as boas práticas operacionais de uso da água, os efeitos dessa ação foram menos significativos no setor. No caso das oito impressoras, pode-se identificar uma importante redução no consumo de água por meio da mudança de hábitos operacionais. O maior controle sobre o tempo necessário de escoamento da água para a limpeza dos tinteiros das impressoras foi responsável por uma redução de 13,5\% no consumo médio 
diário desse setor, passando de 13,35 para $11,55 \mathrm{~m}^{3}$. Em termos de consumo específico, a redução foi ainda maior, passando de 27,9 para $18,3 \mathrm{~mL} / \mathrm{m}^{2} \mathrm{PO}$, o que representa uma diminuição de $34,2 \%$ no indicador do setor. Isso demonstra que a queda no consumo da água foi alcançada, apesar do aumento na produção de embalagens ocorrido durante o período de realização das intervenções, reforçando a consistência do resultado.

Realizadas as intervenções comportamentais, trabalhou-se naquelas de ordem física. Sendo assim, o foco inicial foi no setor de ondulação, por ser o maior consumidor de água. Nele, os volumes mais expressivos encontravam-se na produção de vapor em que, diariamente, $41,26 \mathrm{~m}^{3}$ de água de reposição eram consumidos, ou seja, $63 \%$ do total do setor.

Ao se estudarem as características relativas ao consumo de água na geração de vapor, fornecidas pelo fabricante da caldeira, percebeu-se que ela deveria consumir entre 14 e $20 \mathrm{~m}^{3}$ na reposição, ao invés dos 41,26 $\mathrm{m}^{3}$ registrados historicamente. Uma busca por perdas físicas foi realizada na linha da alimentação da caldeira, nos pontos de consumo de vapor e no purgador do tanque de alimentação. Identificou-se que o controle de nível do condensado, existente no tanque de alimentação, era falho e a água perdia-se sob regime contínuo através de seu purgador (Figura 4).

A correção da perda física ocorreu em duas etapas: controle visual do nível da água no tanque de alimentação pelos operadores da caldeira (E1) e o controle automático do nível da água no tanque de alimentação através dos sensores S1 e S2 (E2). Posteriormente, ocorreu uma etapa (E3) de eliminação de desperdício por meio de alteração de processo, na qual o cancelamento do aquecimento da água por vapor vivo no tanque de alimentação proporcionou uma redução ainda maior no consumo de água. A Tabela 2 apresenta as reduções obtidas por meio das intervenções no processo de produção de vapor do setor de ondulação.

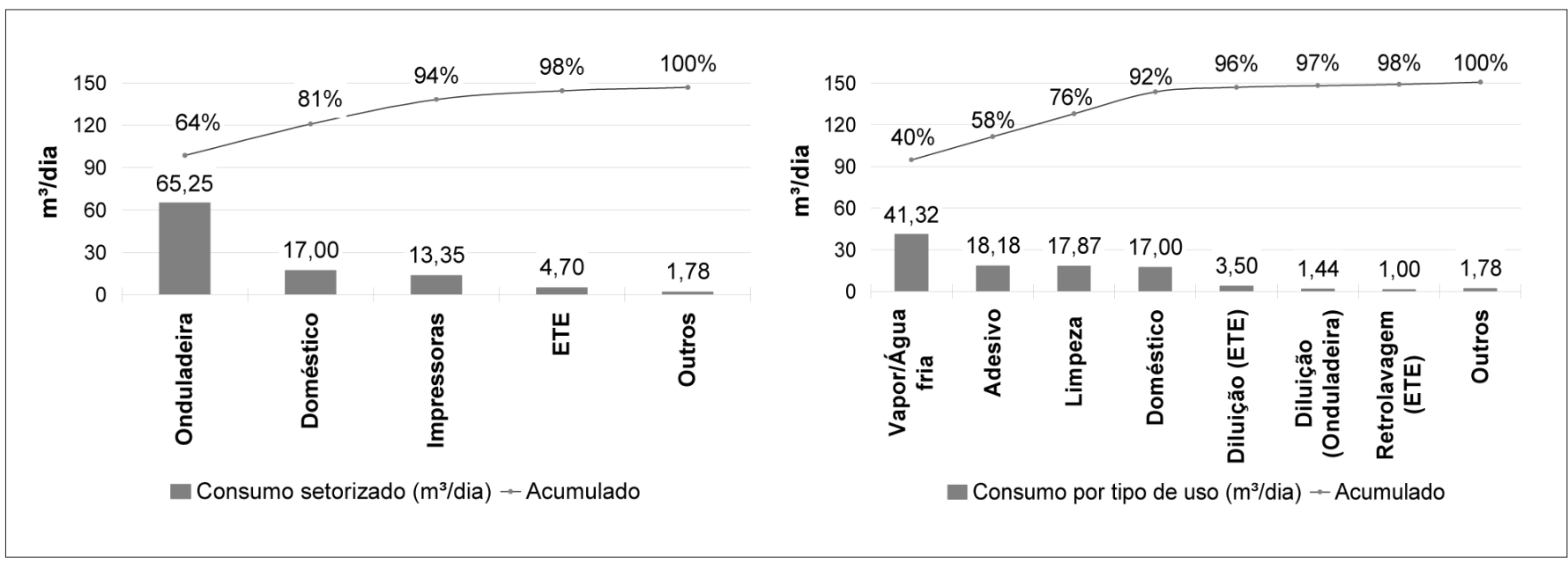

Figura 3 - Distribuição do consumo de água por setor e por tipo de uso. ETE: estação de tratamento de efluentes.

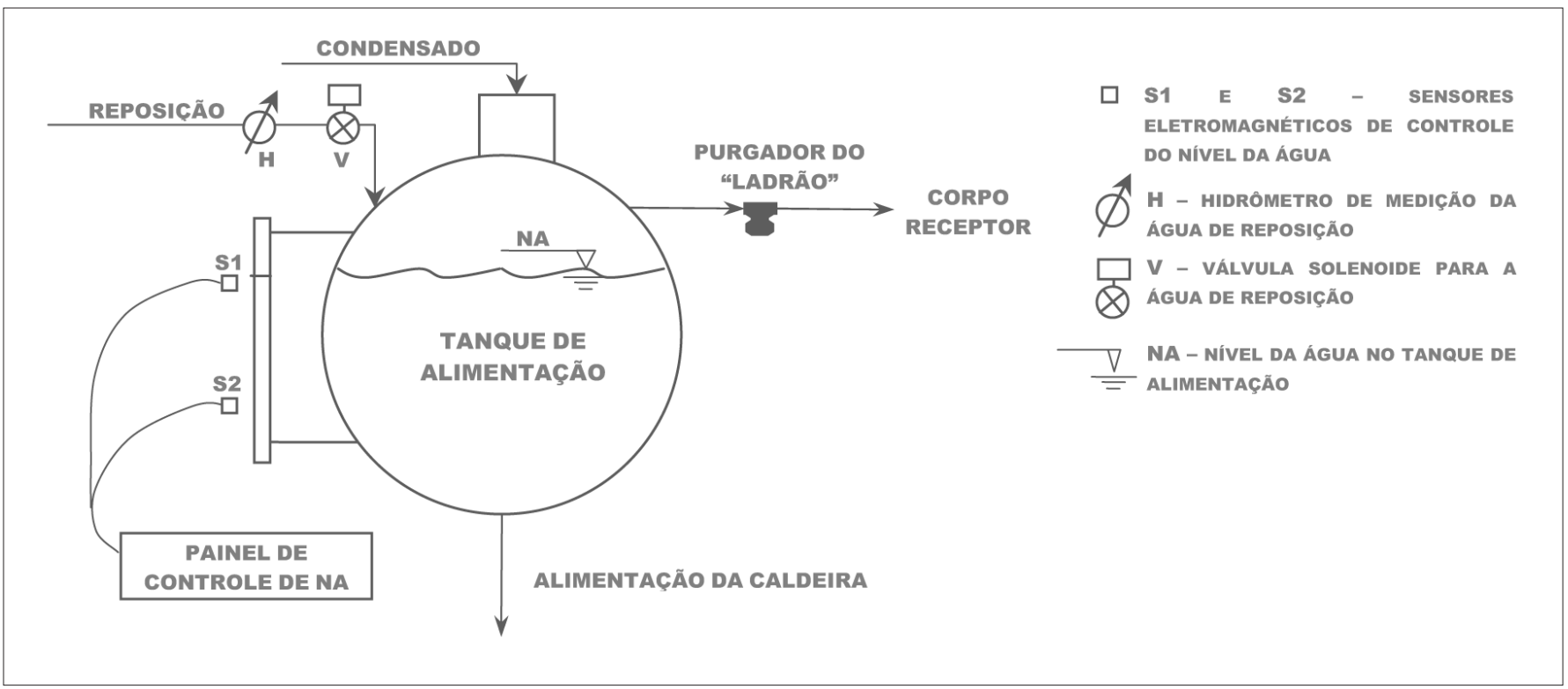

Figura 4 - Representação do tanque de alimentação da caldeira. 
Tabela 2 - Resultados das intervenções de racionalização do uso da água no processo de produção de vapor

\begin{tabular}{lllccc} 
Etapa & \multicolumn{1}{c}{ Ação } & \multicolumn{1}{c}{ Tipo } & $\begin{array}{c}\text { Consumo anterior } \\
\left(\mathrm{m}^{3} / \mathrm{dia}\right)\end{array}$ & $\begin{array}{c}\text { Consumo final } \\
\left(\mathrm{m}^{3} / \mathrm{dia}\right)\end{array}$ & $\begin{array}{c}\text { Redução } \\
(\%)\end{array}$ \\
E1 & Controle visual do NA no tanque de alimentação & Eliminação de perdas & 41,26 & 30,68 & 25,6 \\
E2 & Controle automático do NA no tanque de alimentação & Eliminação de perdas & 30,68 & 23,04 & 24,9 \\
E3 & $\begin{array}{l}\text { Cancelamento do aquecimento da água no tanque de } \\
\text { alimentação }\end{array}$ & Alteração de processo & 23,04 & 15,36 & 33,3 \\
Final & & & 41,26 & 15,36 & 62,8
\end{tabular}

NA: nível da água.

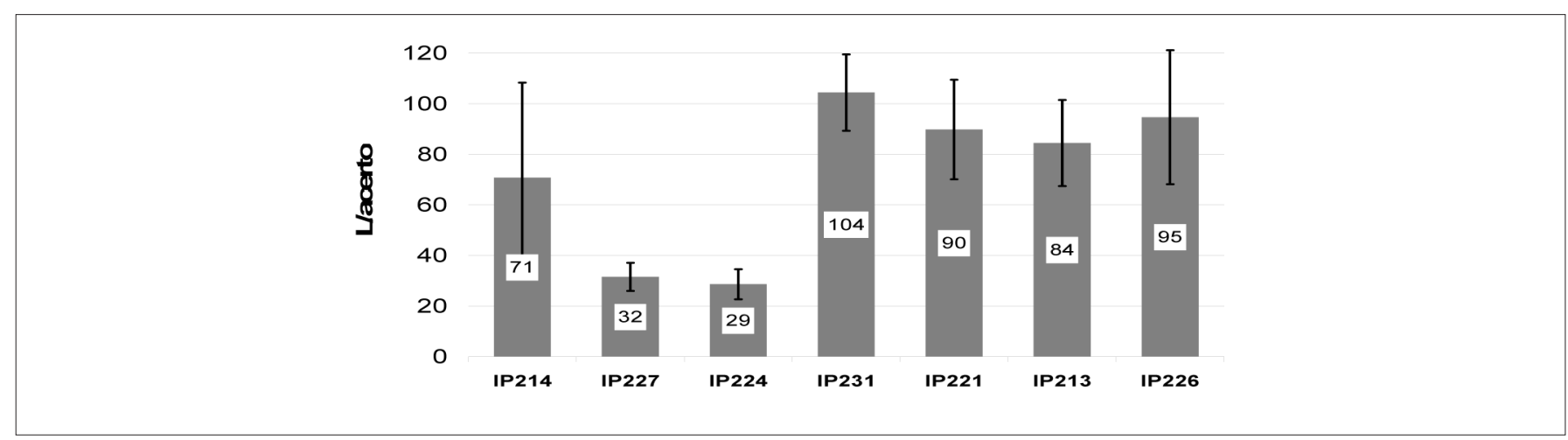

Figura 5 - Consumo específico médio de água nas impressoras, em L/acerto, e seu desvio padrão. IP: impressora.

Seguindo-se a ordem das atividades que mais consumiam água, conforme mostra a Figura 3, tem-se a produção de adesivo como segundo maior consumo. A primeira opção de racionalização, nesse caso, seria a redução de aplicação de adesivo sobre o papel, com a consequente redução no consumo de água; contudo, a onduladeira existente na planta já detém tecnologia de aplicação precisa de adesivo. Esse fato pode ser comprovado por meio do comparativo com a onduladeira anterior, que tinha o consumo de água de $52,3 \mathrm{~mL} / \mathrm{m}^{2}$ $\mathrm{PO}$, superior aos $38,0 \mathrm{~mL} / \mathrm{m}^{2} \mathrm{PO}$ atuais.

O terceiro maior consumo produtivo de água ocorria na limpeza de máquinas e equipamentos. No setor de impressão, conforme se pode verificar na Figura 5, existe uma diferença significativa entre a demanda de água de limpeza das impressoras IP224 e IP227 e a demanda das demais. A análise comparativa dos ciclos de lavagem dessas máquinas mostrou a importância da diferença tecnológica. As IP224 e IP227 apresentam sistema automático de limpeza, o que lhes atribui um consumo médio, pelo menos, 50\% inferior ao das outras máquinas instaladas. Além desse ganho, a automação do processo de lavagem proporciona menor variabilidade do consumo de água, como pode ser observado a partir de seu desvio padrão (Figura 5). Ou seja, a demanda por água nos processos de limpeza fica menos suscetível aos erros humanos que, nesse caso, são provenientes do uso sem critério de volumes de água, muitas vezes excessivos, durante as operações de limpeza.

Com base na análise da Figura 5, pode-se concluir que, automatizando a limpeza de todas as impressoras, haveria uma redução aproximada de $40 \%$ no consumo diário médio no setor, ou seja, o consumo passaria de 11,55 para $6,93 \mathrm{~m}^{3} / \mathrm{dia}$.

\section{Reúso da água}

A identificação das oportunidades de reúso da água iniciou-se pela determinação dos tipos de uso que permitiriam essa prática. Na Tabela 3, são apresentados os tipos T1 a T5, nos quais se poderia realizar o reúso não-potável. A análise dos dados fornecidos pelos hidrômetros resultou nas faixas de consumo apresentadas na Tabela 3, as quais são necessárias para a alocação posterior da água de reúso em cada atividade consumidora.

As seguintes fontes de oferta de água de reúso foram consideradas para o reúso de efluentes brutos: efluente de limpeza das impressoras e efluente de limpeza da onduladeira. Para o reúso de efluentes tratados, consideraram-se as seguintes fontes: efluente do tratamento primário e efluente do tratamento terciário da ETE.

Dentre as fontes de oferta de efluente bruto, aquele gerado na limpeza da onduladeira foi a primeira hipótese a ser avaliada. Apresentando valores de $\mathrm{pH}$ na faixa de 10 a 13, teor de sólidos acima de $10 \%$ e alta biodegradabilidade devido à presença de amido, essa corrente líquida foi desqualificada tecnicamente para esse tipo de reúso.

A água de limpeza das impressoras, segundo o artigo técnico da TAPPI (2001), poderia ser reusada na produção de adesivo de amido. Contudo, o mesmo artigo cita que, por ser carregado com pigmentos, corantes, detergentes e outros compostos químicos característicos do processo flexográfico de impressão, esse tipo de efluente apresenta teor de sólidos entre 5 e $8 \%$, podendo instabilizar as propriedades de adesão do adesivo. Por conseguinte, essa corrente líquida não foi adotada para a prática de reúso. 
Depois de descartada a possibilidade de reúso de efluentes brutos, avaliou-se o reúso de efluentes tratados. As vazões médias disponíveis, provenientes dos processos de tratamento primário (FP) e terciário (FT) eram, respectivamente, 19,07 e 34,86m³/dia, conforme indica a Figura 6.

A alocação dos volumes de água de FP e FT para os tipos de uso citados na Tabela 3 foi baseada no conceito de prevenção da poluição. Por isso, definiu-se que as atividades que receberiam água de reúso seriam aquelas que consumissem maior volume da fonte de oferta FP, ou seja, aquela com água de menor qualidade e menor nível de tratamento.

Dentre os tipos de uso elencados na Tabela 3, T1 apresentou viabilidade técnica para receber água de reúso de FP. Treadaway e Johnson (1997) adotaram essa prática em uma planta produtora de PO da Georgia-Pacific Corporation, nos Estados Unidos. Na indústria descrita no presente artigo, aplicou-se esse mesmo tipo de reúso, ou seja, a produção de adesivo de amido. O controle de $\mathrm{pH}$ da água de reúso, a dosagem de um biocida e de um agente complexante de cálcio às bateladas de adesivo foram medidas de controle usadas na prevenção da perda de qualidade do adesivo e da formação de incrustação na ondiladeira (OD). O consumo médio de água de reúso para esse fim, após a implantação do sistema, é de 18,6m³/dia na planta estudada.

Esgotadas as possibilidades de reúso de FP, estudou-se a viabilidade técnica de reúso de FT nos tipos T2 a T5 da Tabela 3. A diluição de reagentes do tratamento de efluentes (T2) foi testada em planta por meio da produção de 60 bateladas de coagulante e de polieletrólito floculante no processo primário de tratamento. Nenhum efeito adverso à eficiência do tratamento foi constatado, pois tanto a sedimentabilidade e o volume final de lodo formado quanto o consumo de reagentes permaneceram inalterados durante os testes de reúso.

Nos processos de limpeza industrial (T3), a água de reúso proveniente do tratamento terciário atenderia a todos os padrões de qualidade expressos para a Classe 1 da NBR 13969 (ABNT, 1997), exceto pelos sólidos dissolvidos totais (SDT). Todavia, esse parâmetro não representa riscos ao reúso, uma vez que os índices de Langelier e de Ryznar (METCALF \& EDDY, 2003) indicam que o comportamento dessa água quanto à corrosão ou à formação de depósitos varia entre neutro e levemente incrustante. Além disso, a água de poço que tem outorga para uso industrial também apresenta SDT acima do limite indicado na NBR citada, porém não compromete as atividades atuais de limpeza das máquinas e de seus componentes.

Em T5, ou seja, reúso em descargas sanitárias, a NBR 13969 apresenta limites ainda mais brandos, e não há restrições para SDT; logo, o reúso seria completamente viável perante a norma brasileira citada.

No caso do reúso para a geração de vapor na caldeira (T4), a situação é mais crítica, visto que a alcalinidade e o SDT são muito elevados, mesmo na água proveniente do tratamento terciário. Essa água necessitaria de tratamento adicional que garantisse a qualidade exigida para caldeiras. Embora tecnologias de tratamento, tais como osmose inversa e troca iônica, viabilizem tecnicamente esse reúso, elas só se justificariam economicamente quando aplicadas a sistemas de geração de vapor de maior escala.

Muito embora o reúso de FT em T2, T3 e T5 tenha se demonstrado viável e capaz de consumir entre 18,1 e 30,3m³/dia de água, eliminando a emissão de efluentes ao meio ambiente, ele ainda não foi implantado.

Tabela 3 - Tipos de uso que aceitam reúso não potável da água

\begin{tabular}{|c|c|c|c|c|}
\hline \multicolumn{2}{|c|}{ Tipo de reúso } & Atividade & Consumo de água ( $\left.\mathrm{m}^{3} / \mathrm{dia}\right)$ & Consumo de água acumulado ( $\left.\mathrm{m}^{3} / \mathrm{dia}\right)$ \\
\hline \multirow{2}{*}{ T1 } & \multirow{2}{*}{ Industrial } & Produção de adesivo 1 & $8,0-10,0$ & $8,0-10,0$ \\
\hline & & Produção de adesivo 2 & $8,0-10,0$ & $16,0-20,0$ \\
\hline T2 & Industrial & Diluições na ETE & $3,0-4,0$ & $19,0-24,0$ \\
\hline \multirow{4}{*}{ T3 } & \multirow{4}{*}{ Industrial } & Limpeza da onduladeira & $4,0-5,0$ & $23,0-29,0$ \\
\hline & & Limpeza das impressoras & $10,0-12,0$ & $33,0-41,0$ \\
\hline & & Limpeza de baldes e clichês & $2,0-3,0$ & $35,0-44,0$ \\
\hline & & Limpezas diversas & $0,1-0,3$ & $35,1-44,3$ \\
\hline T4 & Industrial & Geração de vapor e de água refrigerada & $14-18$ & $44,1-54,3$ \\
\hline T5 & Doméstico & Descargas sanitárias & $9-10$ & $58,1-72,3$ \\
\hline
\end{tabular}

ETE: estação de tratamento de efluentes

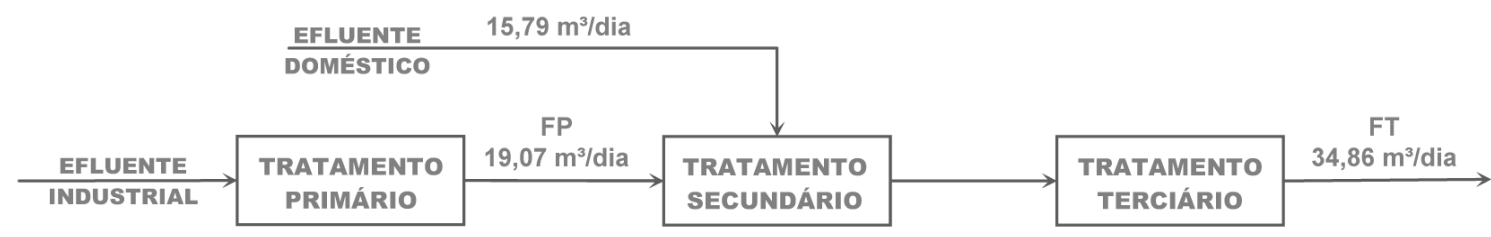

Figura 6 - Diagrama de fluxos simplificado do sistema de tratamento de efluentes (ETE). FP: efluente do tratamento primário; FT: efluente do tratamento terciário. 


\section{Análise dos resultados}

As intervenções implantadas na busca da conservação da água estão descritas na Tabela 4, na qual se observa que um dos resultados da implantação das medidas conservativas foi a redução de $44 \mathrm{~m}^{3} /$ dia na captação de água.

A redução apontada influiu diretamente sobre o consumo médio de água de fontes externas, que passou de 102,09 para 56,31 m²/dia após a realização das intervenções. Como as produções de PO referentes a esses consumos foram de 479.069 e $629.862 \mathrm{~m}^{2} \mathrm{PO} / \mathrm{dia}$, o consumo específico da água passou de 213,11 para $89,41 \mathrm{~mL} / \mathrm{m}^{2} \mathrm{PO}$, ou seja, diminuiu 58,04\%. Esse valor mostra-se bastante abaixo dos $160 \mathrm{~mL} / \mathrm{m}^{2}$ citados em referências internacionais para o setor de PO (WEYERHAEUSER, 2008).

A Figura 7 descreve graficamente o sistema estudado e os fluxos de água e de efluentes internos e externos a ele. Comparativamente à
Figura 2, esse diagrama apresenta um fluxo adicional, representando a linha instalada para reúso da água na produção do adesivo.

É importante notar que as interações do sistema com o meio ambiente são menores quando comparadas ao momento anterior à conservação da água. A captação de água do poço tubular e da concessionária e as perdas de água através do vapor, do lodo e dos efluentes foram reduzidas como consequência das ações voltadas à racionalização do uso e ao reúso da água.

Outra consequência da redução de consumo foi a recuperação do nível médio da água ou profundidade da lâmina d'água do poço, NAP, que passou de 54,10 para 50,74m (medida realizada da superfície até a lâmina). Essa recuperação de nível superou, inclusive, o nível estático máximo identificado em levantamento geológico do poço, o qual era de $51,68 \mathrm{~m}$ antes das intervenções.

A Tabela 5 mostra a alteração das características do efluente final tratado após a aplicação da conservação da água. O reúso de FP em

Tabela 4 - Intervenções conservativas implantadas e suas reduções no consumo de água de fontes externas

\begin{tabular}{|c|c|c|c|c|c|}
\hline \multirow{2}{*}{$\begin{array}{l}\text { Intervenções (I) } \\
\text { Descrição }\end{array}$} & \multirow[b]{2}{*}{ Tipo } & \multicolumn{4}{|c|}{ Consumo da água } \\
\hline & & Tipo/setor de uso & $\begin{array}{l}\text { Antes "I" } \\
\text { (m³/dia) }\end{array}$ & $\begin{array}{l}\text { Após "l" } \\
\text { (m³/dia) }\end{array}$ & $\begin{array}{l}\text { Redução } \\
\text { (\%) }\end{array}$ \\
\hline Treinamento e conscientização & Comportamental & Limpeza/Impressoras & 13,35 & 11,55 & 13,5 \\
\hline Controle do NA no tanque de alimentação & Eliminação de perdas & Vapor/Onduladeira & 41,26 & 23,04 & 44,2 \\
\hline Cancelamento do aquecimento da água na alimentação & Alteração de processo & Vapor/Onduladeira & 23,04 & 15,36 & 33,3 \\
\hline Reúso na produção de adesivo & Reúso & Adesivo/Onduladeira & 18,18 & 2,12 & 88,3 \\
\hline
\end{tabular}

NA: nível da água.

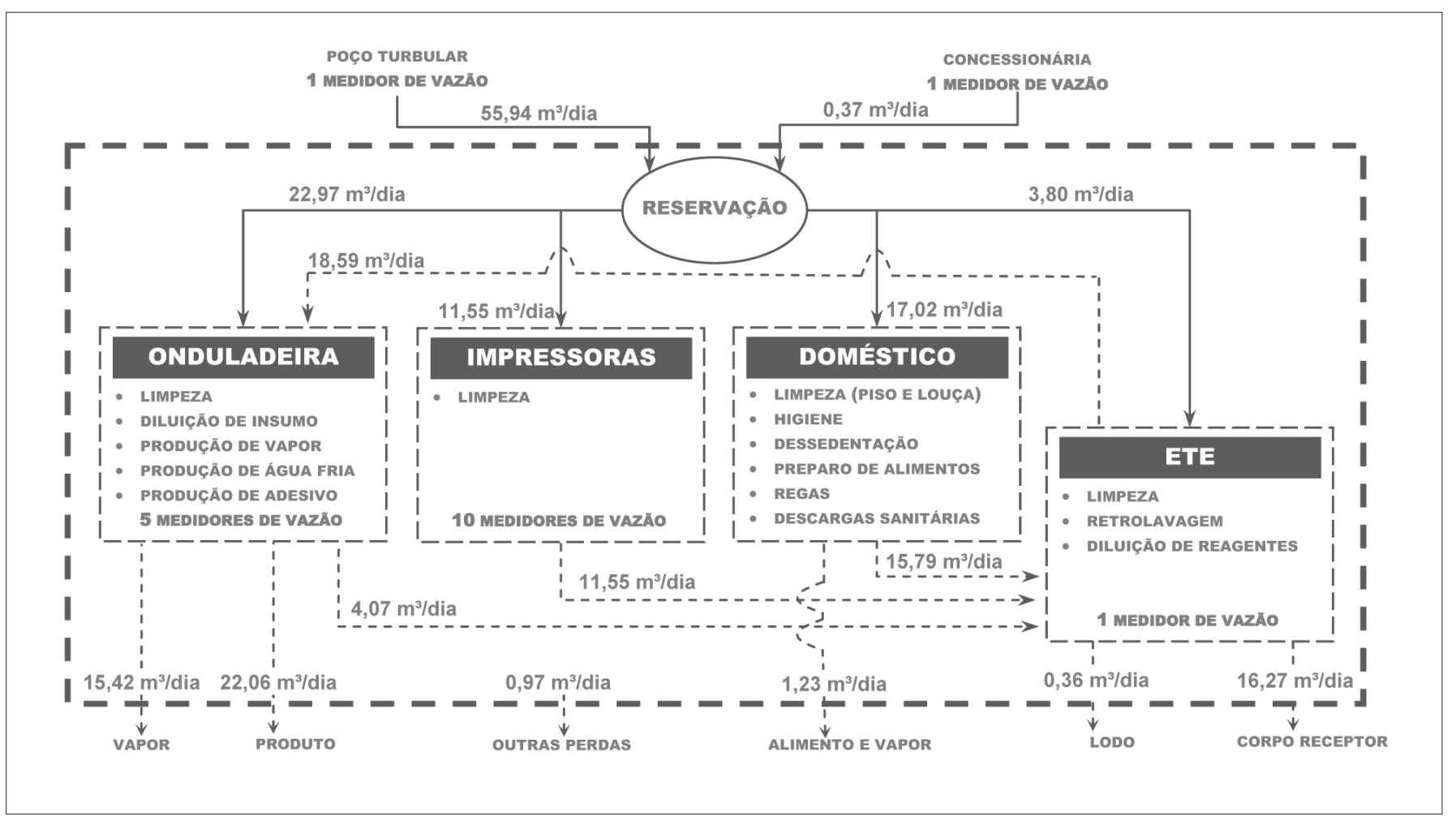

Figura 7 - Diagrama de fluxos para o consumo de água e geração de efluentes após as intervenções (linhas cheias representam os fluxos de água entrando no sistema e nos processos; e as linhas tracejadas, o reúso e as perdas de volumes dos processos e do sistema através de efluentes, vapores e água incorporada ao produto). 
Tabela 5 - Concentrações e cargas de poluentes presentes no efluente lançado ao corpo receptor

\begin{tabular}{|c|c|c|c|c|c|c|}
\hline \multirow{2}{*}{ Período } & \multicolumn{6}{|c|}{ Efluente final tratado } \\
\hline & Vazão ( $\mathrm{m}^{3} /$ dia) & & $\mathrm{DBO}_{5}$ & DQO & NTK & $P_{\text {total }}$ \\
\hline Antes das intervenções & \multirow{2}{*}{37,00} & Concentração (mg/L) & 163,06 & 367,53 & 35,10 & 2,31 \\
\hline $\mathrm{Q}_{\mathrm{ETE}}=37,00 \mathrm{~m}^{3} / \mathrm{dia}$ & & Carga (kg/dia) & 6,03 & 13,60 & 1,30 & 0,09 \\
\hline Após as intervenções & \multirow{2}{*}{16,27} & Concentração (mg/L) & 28,29 & 128,00 & 7,99 & 5,92 \\
\hline$Q_{E T E}=16,27 \mathrm{~m}^{3} / \mathrm{dia}$ & & Carga (kg/dia) & 0,47 & 2,13 & 0,13 & 0,10 \\
\hline Diferença (\%) & & & -92 & -84 & -90 & 10 \\
\hline
\end{tabular}

$\mathrm{Q}_{\mathrm{ETE}}$ : Vazão tratada na estação de tratamento de efluentes.

T1 foi o grande responsável pela redução de 56\% na vazão emitida ao corpo receptor. Além disso, proporcionou a diminuição das cargas afluentes ao tratamento secundário, resultando em um efluente de melhor qualidade em FT. Com exceção do $\mathrm{P}_{\text {total }}$, os demais parâmetros tiveram as cargas poluentes reduzidas em mais de $80 \%$.

Relativamente à legislação aplicável à emissão de efluentes, após a conservação da água, apenas o $\mathrm{P}_{\text {total }}$ permaneceu não atendendo aos padrões de lançamento. Esse problema pode ser contornado através da adição de matéria orgânica carbonácea no afluente do sistema de lodos ativados. Desse modo, se corrigiria a relação $\mathrm{DBO}_{5}: \mathrm{NTK}: \mathrm{P}_{\text {total }}$, melhorando a eficiência de remoção do nutriente. Outra solução viável é a dosagem de $\mathrm{FeCl}_{3}$ na entrada do sedimentador secundário, precipitando o fósforo que seria removido juntamente com os descartes de lodo ativado.

Os limites estabelecidos na outorga de uso da água do poço passaram a ser atendidos plenamente, pois todos os registros de vazões respeitaram o limite máximo de $120 \mathrm{~m}^{3} /$ dia.

\section{Conclusão}

A conservação da água, por meio do uso racional e do reúso, é uma ferramenta eficaz na preservação dos recursos hídricos. O estudo demonstrou que os ganhos ambientais são obtidos tanto na redução da captação de água quanto na redução da emissão de poluentes ao meio ambiente, preservando esse recurso natural em quantidade e qualidade.
As intervenções de ordem comportamental e física devem preceder o reúso da água, pois trazem maiores benefícios ambientais pela eliminação ou redução do seu uso. O reúso, por outro lado, proporciona apenas a substituição de uma água de qualidade superior por outra de qualidade mínima necessária à atividade em questão. Ou seja, não promove aumento na eficiência de uso da água.

Embora os ganhos proporcionados pelas técnicas aplicadas tenham sido expressivos, ainda há um grande potencial de conservação de água na planta estudada. A automação dos sistemas de limpeza das impressoras, seguida pelo reúso na diluição de reagentes da ETE, nos processos de limpeza e nas descargas sanitárias possibilitariam a eliminação da emissão de efluentes ao corpo receptor e a consequente redução no consumo de água do poço em 16,18m²/dia. Caso sejam estudadas e adotadas fontes alternativas de água, tais como a água de chuva, a redução no consumo de água do poço poderia chegar a mais de $30 \mathrm{~m}^{3} /$ dia devido à demanda ainda existente.

O consumo específico da água, considerando-se esse potencial de redução, chegaria a $41,2 \mathrm{~mL} / \mathrm{m}^{2} \mathrm{PO}$, o que representa menos de $50 \%$ do valor obtido após a realização das intervenções atuais.

Estudos de caso como este demonstram a carência da área industrial por estudos específicos voltados à conservação da água. A falta de padrões de qualidade para reúso dificulta a implantação dessa prática que, quando adotada sem critérios, pode trazer riscos aos equipamentos e à saúde humana. A criação de bancos de dados com critérios de qualidade específicos demonstra-se necessária à implantação bem sucedida da conservação na indústria.

\section{Referências}

ASSOCIAÇÃO BRASILEIRA DE NORMAS TÉCNICAS (ABNT). NBR 13969 - Tanques sépticos - Unidades de tratamento complementar e disposição final dos efluentes líquidos - Projeto, construção e operação. Rio de Janeiro: ABNT, 1997.

CORRAL-VERDUGO, V. A structural model of pro-environmental competency. Environment \& Behavior, v. 34, p. 531-549, 2002.

DANISH ENVIRONMENTAL PROTECTION AGENCY (DEPA). 1998. Survey of azo-colorants in Denmark: consumption, use, health and environmental aspects. Disponível em: <http://www.mst.dk/udgiv/
Publications/1999/87-7909-548-8/pdf/87-7909-546-1.pdf>. Acesso em: 14 set. 2009.

FEDERAÇÃO DAS INDÚSTRIAS DO ESTADO DO RIO DE JANEIRO (FIRJAN). Manual de conservação e reúso da água na indústria. Rio de Janeiro: DIM, 2006

FEDERAÇÃO DAS INDÚSTRIAS DO ESTADO DE SÃO PAULO (FIESP). 2004. Conservação e reúso de água: manual de orientações para o setor industrial. v. 1. Disponível em: < http://www.fiesp.com.br/publicacoes/ pdf/ambiente/reuso.pdf>. Acesso em: 5 ago. 2005. 
MANCUSO, P.C.S.; SANTOS, H.F. Reúso de água. São Paulo: Manole, 2003.

METCALF \& EDDY, Inc. Wastewater engineering: treatment, disposal and reuse. 4. ed. New York: McGraw-Hill, 2003.

NEW MEXICO OFFICE OF THE STATE ENGINEER. 1999. A water conservation guide for commercial, institutional and industrial users. Disponível em: <http://www.ose.state.nm.us/water-info/conservation/ pdf-manuals/cii-users-guide.pdf>. Acesso em: 12 jun. 2009.

SANS, R. et al. Minimization of water use and wastewater contaminant load. Journal of Cleaner Production, v. 6, n. 3-4, p. 365-369, 1998.

SAUTCHÚK, C.A. Formulação de diretrizes para implantação de programas de consenvação de água em edificações. Dissertação (Mestrado em Engenharia), Escola Politécnica da Universidade de São Paulo, São Paulo, SP, 2004.
TECHNICAL ASSOCIATION OF THE PAPER AND PULP INDUSTRY (TAPPI). 2001. Using washup water as the vehicle in starch based corrugating adhesive. Technical Information Paper TIP 0304-44. Disponível em: <http://www.tappi.org/Hide/branded-links/EducationalResource-4021-425225/Standards/TIPs/Corrugated-Packaging/UsingWashup-Water-as-the-Vehicle-in-Starch-Based-Corrugating-AdhesiveTechnical-Information-Paper-.aspx>. Acesso em 23 ago. 2009.

TREADAWAY, E.; JOHNSON, U. Recycling treated process wastewater in starch adhesive at a corrugated packaging plant. TAPPI proceedings. Environmental Conference \& Exhibit. v. 2, p. 149-150, 1997.

WAN ALWI, S.R. et al. A holistic framework for design of cost-effective minimum water utilization network. Journal of Environmental Management, v. 88, n. 2, p. 219-252, 2008.

WEYERHAEUSER. 2008. 2007 Sustainability report. Disponível em: <http://www.weyerhaeuser.com>. Acesso em: 2 mar. 2009. 